Article

\title{
Novel Cytoplasmic Bacteriocin Compounds Derived from Staphylococcus epidermidis Selectively Kill Staphylococcus aureus, Including Methicillin-Resistant Staphylococcus aureus (MRSA)
}

\author{
In-Taek Jang ${ }^{1}$, Miso Yang ${ }^{1}$, Hwa-Jung Kim ${ }^{1}$ and Jeong-Kyu Park ${ }^{1,2, *(D)}$ \\ 1 Department of Microbiology and Department of Medical Science, College of Medicine, Chungnam National \\ University, Daejeon 35015, Korea; janginteak@naver.com (I.-T.J.); iammiso@gmail.com (M.Y.); \\ hjukim@cnu.ac.kr (H.-J.K.) \\ 2 Cancer Research Institute, College of Medicine, Chungnam National University, Daejeon 35015, Korea \\ * Correspondence: jekpark@cnu.ac.kr
}

Received: 13 December 2019; Accepted: 27 January 2020; Published: 30 January 2020

\begin{abstract}
Staphylococcus aureus (S. aureus) is one of the well-known agents causing atopic dermatitis (AD) in susceptible individuals, and Staphylococcus epidermidis (S. epidermidis) produces class I thermostable bacteriocins that can selectively kill S. aureus, suggesting protective roles against AD. There is a large need for developing precise therapies only to target $S$. aureus and not to harm the beneficial microbiome. On the agar well diffusion assay, live planktonic S. epidermidis showed clear zones of inhibition of $S$. aureus growth, but heat-killed cells and cell-free supernatants did not show this. These results would lead us to hypothesize that cytoplasmic bacteriocin from $S$. epidermidis will be a promising agent to inhibit $S$. aureus growth. Therefore, we have extracted a novel thermolabile cytoplasmic bacteriocin from S. epidermidis using trichloroactic acid (TCA)/acetone precipitation method after cell lysis with a SDS-containing buffer. These bacteriocin selectively exhibited antimicrobial activity against S. aureus and methicillin-resistance Staphylococcus aureus (MRSA), presenting no active actions against S. epidermidis, E. coli, and Salmonella Typhimurium. The extracted cytoplasmic bacteriocin compounds revealed several diffuse bands of approximately 40-70 $\mathrm{kDa}$ by SDS-PAGE. These findings suggest that these cytoplasmic bacteriocin compounds would be a great potential means for $S$. aureus growth inhibition and topical AD treatment.
\end{abstract}

Keywords: bacteriocin; Staphylococcus epidermidis; Staphylococcus aureus; TCA/acetone precipitation method

\section{Introduction}

Atopic dermatitis (AD) is a chronic inflammatory skin disease that manifests as dry skin and eczematous dermatitis with prominent itch [1]. Despite its complexity, pathogenesis of AD is quite obviously associated with the skin microbiome. Recently, the correlation of Staphylococcus aureus (S. aureus) with AD during active disease exacerbation has been well documented [2-5]. AD is a long-standing inflammatory skin disease typified by epidermal barrier dysfunction that can affect the bacterial community of the skin. A S. aureus cell wall product, lipoteichoic acid (LTA), is shown to cause skin barrier damage by inhibiting the expression of epidermal barrier proteins filaggrin and loricrin. Dysbiosis contributes to the pathogenesis of AD by both detrimental effects from $S$. aureus and by loss of beneficial effects from some members of the microbiome. S. aureus secretes a pore-forming, phenol soluble modulins (PSMs, $\delta$-toxin) which destroys the skin barrier and promotes skin inflammation as a fuel for dermal mast cells. AD patients frequently demonstrate increased levels 
of IgE and production of IgE specific for staphylococcal superantigens whose levels are positively correlated with AD severity [6,7]. In our previous study, we found that live planktonic S. aureus or methicillin-resistant $S$. aureus (MRSA) induced human mast cell degranulation, but no effect had been found in heat-killed bacteria [8].

Current treatments for $\mathrm{AD}$ with the usage of topical steroids improve dermatitis due to their strong anti-inflammatory effect. However, skin thinning with long-term use and recurrence of dermatitis after discontinuation are highly associated [9]. In order to compensate for these limitations in those conventional topical steroid treatments, several attempts have been made to achieve the removal of colonized S. aureus. However, studies imply that topical antibiotic therapy would not be able to reduce bacteria counts and theoretically protect the normal skin microbiome [10]. Furthermore, the frequent use of pharmaceutical antibiotics promotes antibiotic resistance [11]. Consequently, there is a rising need again to develop pathogen-specific precision therapies only to target the infectious pathogens and not to harm the beneficial microbiome.

Multiple studies are currently focused on the manipulation of the skin microbiome to explore its therapeutic potential. The colonizing bacteria (S. epidermidis) are probably in strong competition and may use a variety of strategies to overcome competitors (S. aureus). Bacteria from human microbiota have occasionally been found producing bacteriocins, antimicrobial substances that show an activity against closely related bacteria [12]. Bacteriocins produced by S. epidermidis have bactericidal effects towards S. aureus. These antimicrobial peptide-producing coagulase-negative Staphylococcus (CoNS) strains are less frequent in atopic individuals, and the reintroduction of CoNS decreases S. aureus colonization. It has been reported that transplant of S. hominis and S. epidermidis strains secreting antimicrobial peptides (AMPs) is effective in controlling S. aureus overgrowth $[7,13]$. However, $S$. epidermidis is an opportunistic pathogen holding an emerging risk factor in hospitals worldwide and is often difficult to eradicate due to its virulent strains producing a protective biofilm matrix [14,15]. Therefore, single $S$. aureus targeting bacteriocin can become a valuable strategy for preventing $S$. aureus colonization.

S. epidermidis ATCC12228 is an avirulent, non-infection-associated and non-biofilm-forming strain. The bacteriocins produced by this S. epidermidis strains are low-molecular-weight (lower than $5 \mathrm{kDa})$ and heat-stable class I lantibiotics. The low-molecular-weight $(<100 \mathrm{kDa})$ proteins are not observed in cell-free supernatant (CFS) from S. epidermidis ATCC12228. The majority of the identified proteins $(\sim 80 \%)$ were predicted to be cytoplasmic in this strain. This indicates that these proteins are expressed but not exported by S. epidermidis ATCC12228 [16,17]. We also observed that live planktonic S. epidermidis ATCC12228 generated a clear zone of growth inhibition S. aureus ATCC 25923, but heat-killed cells and CFS did not show any activities on the agar well diffusion assay. These results revealed that this strain itself could not spontaneously secrete bacteriocins into the CFS at a level of sufficiency directly to inhibit $S$. aureus.

Thus, the aim of this study was to extract cytoplasmic bacteriocin compounds from S. epidermidis ATCC12228 by TCA/acetone precipitation method after cell lysis with SDS-containing buffer. We suggest that the application of cytoplasmic bacteriocin compounds in this strain is a safer and more effective therapeutic method than those of live S. epidermidis for the growth inhibition of S. aureus in AD. Herein, we describe the partial purification and characterization of the novel thermolabile cytoplasmic bacteriocin compounds from cell extract of the S. epidermidis strain. These bacteriocin compounds from S. epidermidis are a novel bacteriocin that have potential applications in management of AD.

\section{Results}

\subsection{Antimicrobial Activity of Live Planktonic S. epidermidis or CFS from S. epidermidis}

S. epidermidis (ATCC12228 and NCCP14768) were screened for antimicrobial activity against S. aureus (ATCC25923, NCCP14780 and MRSA), E. coli and Salmonella Typhimurium by agar well diffusion assay. Both live planktonic $S$. epidermidis strains showed antimicrobial activity against all $S$. 
aureus strains displaying clear zones as a result of inhibition, but heat-killed cells did not show any activities [Figure 1A]. None of the S. epidermidis strains observed inhibition zones for all S. aureus strains with the treatment of CFS only [Figure 1B]. The inhibition ability of live planktonic S. epidermidis was detected against $S$. aureus ATCC25923 (11.1 $\pm 0.1 \mathrm{~mm})$, S. aureus NCCP14780 $(11.4 \pm 0.2 \mathrm{~mm})$ and MRSA ATCC33591 (10.6 $\pm 0.1 \mathrm{~mm})$. No inhibition activity was observed in S. epidermidis, E. coli and Salmonella Typhimurium with the combined treatment of both live planktonic strains and CFS [Table 1]. The results suggested that the live planktonic S. epidermidis selectively kill S. aureus, including MRSA.

Target S. aureus

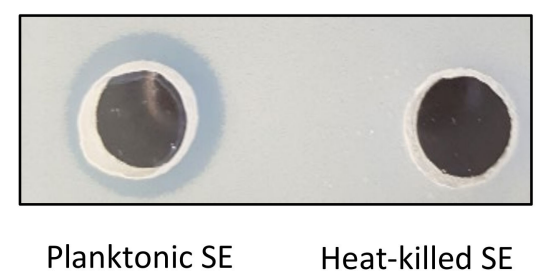

(A)
Target S. aureus

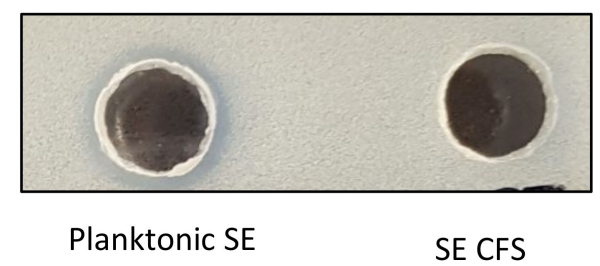

(B)

Figure 1. The planktonic S. epidermidis ATCC12228 (SE) showed antimicrobial activity against S. aureus ATCC 25923 on the agar well diffusion assay but heat-killed S. epidermidis (A) and cell-free supernatant (CFS) (B) from S. epidermidis did not show any activities.

Table 1. The diameters of antibacterial inhibitory zones in the live planktonic S. epidermidis (PCSE) and CFS from S. epidermidis ATCC12228 against bacterial indicators.

\begin{tabular}{lcc}
\hline \multicolumn{1}{c}{ Bacterial indicators } & PCSE & CFS \\
\hline S. aureus (ATCC 25923) & $11.1 \pm 0.1$ & - \\
S. aureus (NCCP 14780) & $11.4 \pm 0.2$ & - \\
MRSA (ATCC 33591) & $10.6 \pm 0.1$ & - \\
S. epidermidis (ATCC 12228) & - & - \\
E. coli (NCCP 14762) & - & - \\
Salmonella Typhimurium & - & - \\
(NCCP 10438) & & \\
\hline
\end{tabular}

Note: CFS = cell-free supernatant; $(-)=$ no inhibition activity; Results of inhibition zone (mm) including $6 \mathrm{~mm}$ well diameter is given as the mean value of the triplicate trials \pm SD (standard deviation).

The average $\mathrm{pH}$ of skin surfaces lies between 5.0 and 6.0. The effect of $\mathrm{pH}$ in culture medium on the production of the cytoplasmic bacteriocin compounds has been assessed. The inhibition zone of intra-cytoplasmic protein (IP) from S. epidermidis ATCC12228 at pH $5.0(10.8 \pm 0.1 \mathrm{~mm})$ or $6.0(10.4 \pm$ $0.2 \mathrm{~mm})$ present more prominent actions than that of $\mathrm{pH} 7.4(8.6 \pm 0.1 \mathrm{~mm})$ against $S$. aureus or MRSA. No antimicrobial activity was observed on the CFS with overnight growth culture of S. epidermidis (Figure 2).

\subsection{Antimicrobial Activity of Concentrated Proteins from CFS of S. epidermidis Strains}

As S. epidermidis grown on the agar well diffusion assay generated a clear zone of inhibition of $S$. aureus growth but not in CFS, it is necessary to isolate sufficient amounts of bacteriocin for the antimicrobial activity. Thus, we precipitated CFS by 10\% TCA and precipitated proteins were re-suspended with solubilization solution. The precipitated proteins of CFS did not show any antimicrobial activity against all $S$. aureus on agar well diffusion assay, but the reference strain of Bacillus subtilis showed the antimicrobial activities toward S. aureus (data not shown). 


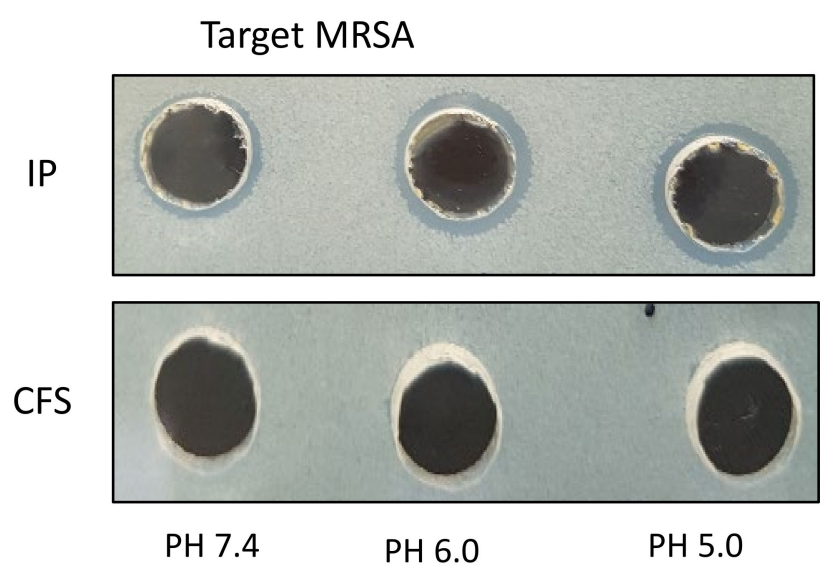

Figure 2. The effect of culture medium $\mathrm{pH}$ on the production of the cytoplasmic bacteriocin compounds. The inhibition zone of intra-cytoplasmic protein (IP) from S. epidermidis ATCC12228 at pH 5.0 or 6.0 was more prominent than $\mathrm{pH} 7.4$ against $S$. aureus or methicillin-resistant $S$. aureus (MRSA). No antimicrobial activity was observed in the CFS with the overnight growth of S. epidermidis.

\subsection{Antimicrobial Activity of Cytoplasmic Bacteriocin Compounds from S. epidermidis Strains}

Inquiries came from where live planktonic S. epidermidis only have the antimicrobial activity against all $S$. aureus, but not CFS or precipitate proteins of CFS on the agar well diffusion assay. To answer this question, we performed the extraction of cytoplasmic proteins from dried S. epidermidis by TCA/acetone precipitation method after lysis by SDS-containing buffer.

The extracted cytoplasmic bacteriocin compounds were tested for antimicrobial activity against $S$. aureus by agar well diffusion method. The production of a clear zone by growth inhibition was noted. The antimicrobial activity of cytoplasmic bacteriocin compounds were found to be stable after heating at $45^{\circ} \mathrm{C}$ for $20 \mathrm{~min}$. However, it seemed that it lost its antimicrobial activities on heating to $100^{\circ} \mathrm{C}$ for 20 min (Figure 3).

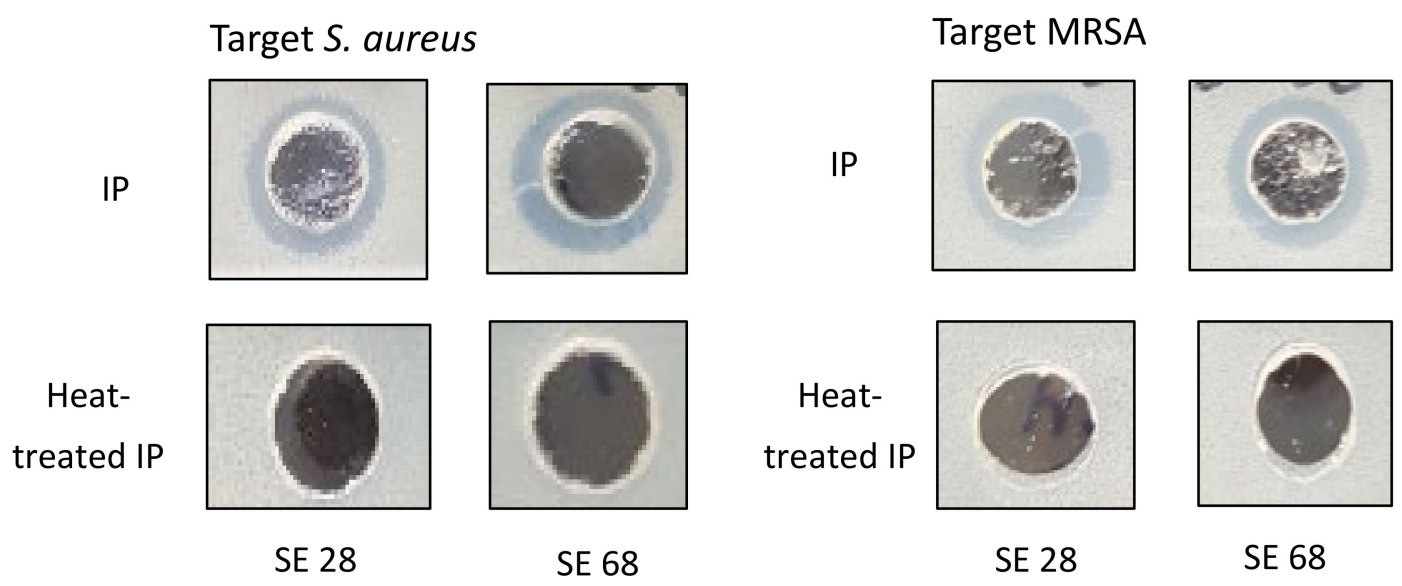

Figure 3. The antimicrobial activities of the intra-cytoplasmic protein (IP) from S. epidermidis ATCC12228 (SE 28) or NCCP14768 (SE 68) against S. aureus or MRSA. The antimicrobial activity was found to be stable after heating at $45^{\circ} \mathrm{C}$ for $20 \mathrm{~min}$ but lost its actions heating to $100{ }^{\circ} \mathrm{C}$ for $20 \mathrm{~min}$.

\subsection{The Minimum Bactericidal Concentration of Cytoplasmic Bacteriocin Compounds}

On the agar well inhibition assay, the concentration ranges of cytoplasmic bacteriocin from $2 \mathrm{mg}$, $1 \mathrm{mg}, 500 \mu \mathrm{g}, 250 \mu \mathrm{g}$, and $125 \mu \mathrm{g} / \mathrm{ml}$ in each well and the diameter of growth inhibition area was 
measured as $14.4 \pm 0.2,12.1 \pm 0.1,10.2 \pm 0.2 \mathrm{~mm}, 8.3 \pm 0.1 \mathrm{~mm}$, and none, respectively [Figure 4]. Based on our experiments, $250 \mu \mathrm{g} / \mathrm{ml}$ concentration yields $10.2 \pm 0.2 \mathrm{~mm}$ the diameter of the growth inhibition zone. We conducted the various concentration ranges from above/below the $250 \mu \mathrm{g} / \mathrm{ml}$ concentration. Antimicrobial activity of cytoplasmic compounds from S. epidermidis ATCC12228 at a concentration of $125 \mu \mathrm{g} / \mathrm{ml}$ did not exhibit a growth inhibitory effect on S. aureus ATCC25923. Therefore, the minimum bactericidal concentration of cytoplasmic bacteriocin compounds was $250 \mu \mathrm{g} / \mathrm{ml}$.

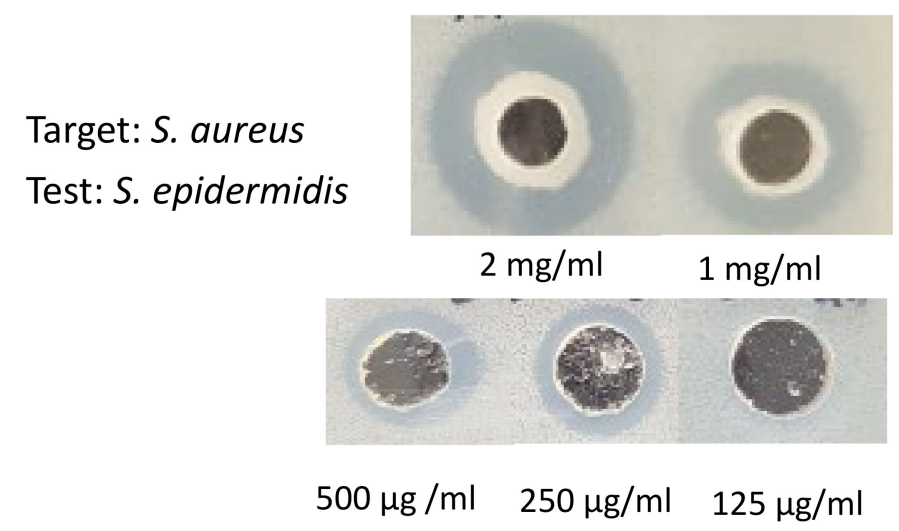

Figure 4. On the agar well inhibition assay, the concentration of cytoplasmic bacteriocin compounds from S. epidermidis ATCC12228 showing from $2 \mathrm{mg}, 1 \mathrm{mg}, 500 \mu \mathrm{g}, 250 \mu \mathrm{g}$, and $125 \mu \mathrm{g} / \mathrm{ml}$ in each well. Antimicrobial activity decreased with decrease in its concentration. There is no antimicrobial activity of cytoplasmic bacteriocin compounds from S. epidermidis ATCC12228 at concentration of $125 \mu \mathrm{g} / \mathrm{ml}$ against S. aureus ATCC25923.

\subsection{The Molecular Weight Ranges of Partially Purified Cytoplasmic Bacteriocin Compounds}

The molecular weight of partially purified cytoplasmic bacteriocin compounds was determined by SDS-PAGE gel electrophoresis method. The examination of the cytoplasmic bacteriocin compound profiles by SDS-PAGE exposed several diffuse bands of approximately 40-70 kDa [Figure 5].

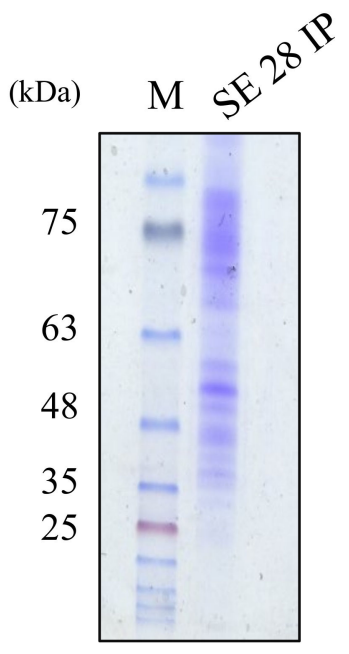

Figure 5. A bacteriocin compound profiles of SDS-PAGE of S. epidermidis ATCC12228, lane M: Molecular weight marker; Lane SE 28 IP: partially purified intra-cytoplasmic protein (IP) from $S$. epidermidis ATCC12228. 


\section{Discussion}

In this present study, the live planktonic S. epidermidis ATCC12228 showed a specific antimicrobial activity targeting only $S$. aureus strains with clear zones of inhibition on the agar well diffusion assay, whereas heat-killed S. epidermidis showed no growth inhibition areas [Figure 1]. No inhibitory actions were observed in S. epidermidis, E. coli and Salmonella Typhimurium with both live planktonic strains and CFS [Table 1]. The results suggested that the only live planktonic S. epidermidis selectively kill $S$. aureus, including MRSA.

Dysbiosis contributes to the pathogenesis of $\mathrm{AD}$ in both detrimental effects from S. aureus and loss of beneficial effects from some members of the microbiome. Pharmaceutical antibiotics have been used to inhibit $S$. aureus in the management of $\mathrm{AD}$, but their efficacy on the skin is limited and has disadvantages in that they may kill beneficial strains and break mutualistic interactions between the skin and microbial communities. High potential antimicrobials may result in a short-term improvement, but they can subsequently increase a long-term risk by causing dysbiosis and promoting antibiotic resistance $[7,13,18]$.

Human skin is highly tolerant to exposure to S. epidermidis, which may contribute to the colonization of human skin by S. epidermidis as a permanent commensal. Although the role of S. epidermidis in skin biology is still emerging, there is increasing evidence that $S$. epidermidis plays an important role in skin defense especially by directly restricting the growth of pathogenic bacteria such as S. aureus and activation of immune cells. CoNS are typically low virulence organisms that commonly colonize the skin and mucous membranes. CoNS, including S. epidermidis, compete with S. aureus for stable colonization of human skin reservoirs by production of antimicrobial factors $[7,9,19]$.

Live planktonic S. epidermidis have the antimicrobial activity only against all S. aureus, but not CFS or precipitated proteins of CFS on the agar well diffusion assay. Low-molecular-weight $(<100$ $\mathrm{kDa}$ ) proteins from S. epidermidis ATCC 12228 are expressed but not exported into CFS [16]. Therefore, it is necessary to extract cytoplasmic bacteriocin compounds from dried S. epidermidis by TCA/acetone precipitation method after lysis by SDS-containing buffer.

The extracted cytoplasmic bacteriocin compounds were tested for antimicrobial activity against $S$. aureus by the agar well diffusion method. The production of a clear zone of growth inhibition was noted. The inhibition zone of intra-cytoplasmic protein (IP) from S. epidermidis ATCC 12228 at pH 5.0 or 6.0 was more prominent than $\mathrm{pH} 7.4$ against $S$. aureus or MRSA [Figure 2]. The skin surfaces $\mathrm{pH}$ is on average between 5.0 and 6.0 [20]. The production of cytoplasmic bacteriocin compounds at acid condition was enhanced when compared with neutral $\mathrm{pH}$. The antimicrobial activity of cytoplasmic bacteriocin compounds was found to be stable after heating at $45^{\circ} \mathrm{C}$ for $20 \mathrm{~min}$ but lost its activities heating to $100{ }^{\circ} \mathrm{C}$ for $20 \mathrm{~min}$ [Figure 3]. The minimum bactericidal concentration of cytoplasmic bacteriocin compounds was taken as the lowest concentration that did not allow $S$. aureus growth on the agar well inhibition assay [Figure 4]. Therefore, the minimum bactericidal concentration of cytoplasmic bacteriocin compounds was $250 \mu \mathrm{g} / \mathrm{ml}$. The extracted cytoplasmic bacteriocin compounds revealed several diffuse bands of approximately 40-70 kDa by SDS-PAGE [Figure 5].

Based on bacteriocin primary structure, molecular mass, heat stability and molecular organization, bacteriocins are divided into three classes. Class I lantibiotics are thermostable peptides of molecular weight below $5 \mathrm{kDa}$. Class II non-lantibiotics are thermostable bacteriocins of molecular weight below $10 \mathrm{kDa}$. Class III includes thermolabile bacteriocins of molecular weight above $30 \mathrm{kDa}$. The majority of bacteriocin from S. epidermidis strains are thermostable class I lantibiotics $[2,6,21,22]$. It has been reported that the production of type I, II thermostable bacteriocins and phenol-soluble modulins (PSM8; MW 3kDa) by S. epidermidis can selectively kill bacterial pathogens such as S. aureus [23,24]. Iwase et al. (2010) [25] also have shown that a subset of biofilm inhibitory S. epidermidis eliminates $S$. aureus by secreting $27 \mathrm{kDa}$ serine protease (Esp), but non-inhibitory S. epidermidis (Esp-negative strain, ATCC12228) did not show the eliminating effect. At present, cytoplasmic protein export mechanisms suggest that some of the cytoplasmic proteins are released from dead cells which then remain attached and decorate the cell walls of bacteria, and the membrane vesicle (MV) type of nonclassical secretion 
mechanism is likely to be exploited by S. epidermidis, allowing the export of cytoplasmic proteins $[16,26]$. Our study contributes to do further extensive research on the secretion mechanisms of the cytoplasmic bacteriocins from S. epidermidis.

Putting together the extracted cytoplasmic bacteriocin compounds from the S. epidermidis ATCC12228 strain were shown to selectively inhibit the growth of $S$. aureus. The result demonstrated that the extracted thermolabile cytoplasmic bacteriocin compound profiles by SDS-PAGE exposed several diffuse bands of approximately $40-70 \mathrm{kDa}$. Thus, the cytoplasmic bacteriocin compounds have potential topical applications in the management of $\mathrm{AD}$.

\section{Materials and Methods}

\subsection{Strains and Growth Conditions}

The Staphylococcal target strains used in this study were S. aureus ATCC25923 (ATCC, Rockville, MD, USA), S. aureus NCCP14780 (NCCP, Seoul, Korea), MRSA (ATCC33591), and the test strains were S. epidermidis (ATCC12228 and NCCP14768). Strain stocks were stored in freeze medium containing $30 \%(\mathrm{w} / \mathrm{v})$ glycerol at $-80^{\circ} \mathrm{C}$. An overnight starter culture of Staphylococcus was grown for $16 \mathrm{~h}$ in Tryptic Soy Broth (TSB; Becton, Dickinson and company, Sparks, MD, USA) at $37^{\circ} \mathrm{C}$ with constant agitation (160 rpm) to be used as an inoculum for the growth experiments. To obtain antimicrobial substances, the overnight culture was diluted 1:100 in Luria broth (LB; LPS solution, Daejeon, Korea) and incubated at $37^{\circ} \mathrm{C}$ with constant agitation (160 rpm) for 4-6 h [27].

\subsection{Preparation of CFS from S. Epidermidis for Antimicrobial Potentiality}

Cells were removed by centrifugation at $3500 \mathrm{rpm}$ for $20 \mathrm{~min}$ and the supernatants were filtered with a membrane of pore size $0.45 \mu \mathrm{m}$, this was then referred to as CFS. The extracellular proteins in the supernatant were precipitated with $10 \%(\mathrm{w} / \mathrm{v}) \mathrm{TCA}$ on ice at $4{ }^{\circ}$ Covernight. The precipitates were harvested by centrifugation at $8000 \mathrm{xg}$ for $20 \mathrm{~min}$ at $4{ }^{\circ} \mathrm{C}$ and washed with ice-cold acetone and dried at $37^{\circ} \mathrm{C}$. The dried protein pellets were stored at $-20^{\circ} \mathrm{C}$ until further use $[28,29]$.

\subsection{Extraction of cytoplasmic bacteriocin compounds from S. epidermidis for antimicrobial potentiality}

After harvesting test strains, cells were washed twice with PBS. The cells were re-suspended in $500 \mu \mathrm{l}$ of SDS Lysis Buffer (2\% SDS, 0.375 M Tris $\mathrm{pH}$ 6.8, 3.4 M sucrose). The re-suspension mixture was thoroughly mixed and sonicated on ice (10 $\mathrm{min}, 30$ s running, 10 s pause, $40 \%$ amplitude) using sonicator (Vibra cell; Sonics \& Materials Inc, Newtown, CT, USA). Cell debris was removed by centrifugation at 14,000 rpm (Hanil Microcentrifuge; Hanil Scientific Inc, Kimpo, Korea) for $30 \mathrm{~min}$. The supernatant containing proteins were precipitated with $10 \%(\mathrm{w} / \mathrm{v})$ TCA on ice at $4{ }^{\circ} \mathrm{C}$ overnight. Finally, the precipitates were collected by microcentrifugation for $30 \mathrm{~min}$ at $4{ }^{\circ} \mathrm{C}$ and washed three times with ice-cold acetone and dried at $37^{\circ} \mathrm{C}$ [30]. Total cytoplasmic protein concentration was determined by the Bradford Assay kit (BioRad, Hercules, CA, USA). The dried protein pellets were stored at $-20^{\circ} \mathrm{C}$ until further use.

\subsection{Stability Tests of Cytoplasmic Bacteriocin Compounds from S. epidermidis}

The susceptibility of partially purified cytoplasmic bacteriocin compounds to temperature was investigated through the agar well diffusion assay. To determine temperature stability, the purified bacteriocin compound was subjected to $45^{\circ} \mathrm{C}$ or $100{ }^{\circ} \mathrm{C}$ for 20 minutes. Antimicrobial activity was then determined by carrying out the agar well diffusion assay with $S$. aureus as the bacterial indicator.

\subsection{Antimicrobial Activity of Bacteriocins by the Agar Well Diffusion Assay}

LB agar plates (1.5\% agar) were overlaid with $4 \mathrm{ml}$ LB soft agar (1\%) having $100 \mu$ lof Staphylococcal target strain. Wells of $6 \mathrm{~mm}$ diameters were bored in agar plates. Precipitated proteins were re-suspended with $150 \mu \mathrm{l}$ of solubilization solution $(25 \mathrm{mM}$ ammonium bicarbonate and $10 \mathrm{mM}$ 
dithiothreitol). Then, $80 \mu \mathrm{l}$ of the re-suspended bacteriocin compound from a different condition was transferred into separate wells. The plates were incubated at $37^{\circ} \mathrm{C}$ overnight and the growth inhibition zones were measured [31].

\subsection{Determination of the Minimum Bactericidal Concentration by the Agar Well Diffusion Assay}

Two-folded serial dilution of the cytoplasmic bacteriocin compounds was prepared ( $2 \mathrm{mg}, 1$ $\mathrm{mg}, 500 \mu \mathrm{g}, 250 \mu \mathrm{g}$, and $125 \mu \mathrm{g} / \mathrm{ml}$ in each well). Then, $80 \mu \mathrm{l}$ of each bacteriocins was transferred into separate wells. The plates were incubated at $37^{\circ} \mathrm{C}$ overnight and the growth inhibition zones were measured. Interpretation of the minimum bactericidal concentration was done as the lowest concentration of the cytoplasmic bacteriocin compounds that did not show any visible inhibition zones of $S$. aureus on the agar well.

\subsection{Molecular Weight Estimation with Sodium Dodecyl Sulfate-Polyacrylamide Gel Electrophoresis (SDS-PAGE)}

The molecular weight of partially purified bacteriocin compounds was determined by SDS-PAGE. The $30 \mu \mathrm{L}$ sample was homogenized with $2 \%$ SDS and dithiothreitol (DTT) added to a little glycerin to increase the density. The sample was heated in boiling water for $5 \mathrm{~min}$, then loaded onto gel along with molecular weight marker and mixed by using a Mini-Protean 4 cell system (Bio-Rad, Hercules, CA, USA), $100 \mathrm{~V}$ and $20 \mathrm{~mA}$ in the separation gel at $\mathrm{pH}$ 8.3. The gel was stained with $50 \mathrm{~mL}$ of Coomassie brilliant blue R-250 ( $0.1 \mathrm{M})$ for 4 hours. The decolorizing solution was decolorized for $12 \mathrm{~h}$ until the electrophoresis band was clear [32].

Author Contributions: Methodology, I.-T.J. and M.Y.; validation, H.-J.K.; investigation and writing, J.K.P. All authors have read and agreed to the published version of the manuscript.

Funding: This work was supported by research fund of Chungnam National University.

Conflicts of Interest: The authors declare no conflict of interest.

\section{References}

1. Kobayashi, T.; Nagao, K. Host-microbial dialogues in atopic dermatitis. Int. Immunol. 2019, 31, 449-456. [CrossRef]

2. Blicharz, L.; Rudnicka, L.; Samochocki, Z. Staphylococcus aureus: an underestimated factor in the pathogenesis of atopic dermatitis? Adv. Dermatol. Allergol. 2019, 36, 11-17. [CrossRef] [PubMed]

3. Kong, H.H.; Oh, J.; Deming, C.; Conlan, S.; Grice, E.A.; Beatson, M.A.; Nomicos, E.; Polley, E.C.; Komarow, H.D.; Murray, P.R.; et al. Temporal shifts in the skin microbiome associated with disease flares and treatment in children with atopic dermatitis. Genome. Res. 2012, 22, 850-859. [CrossRef] [PubMed]

4. Brauweiler, A.M.; Goleva, E.; Leung, N.Y. Staphylococcus aureus Lipoteichoic Acid Damages the Skin Barrier through an IL-1-Mediated Pathway. J. Investig. Dermatol. 2019, 139, 1753-1761. [CrossRef]

5. Nakamura, Y.; Oscherwitz, J.; Cease, K.B.; Chan, S.M.; Muñoz-Planillo, R.; Hasegawa, M.; Villaruz, A.E.; Cheung, G.Y.; McGavin, M.J. Staphylococcus delta-toxin induces allergic skin disease by activating mast cells. Nature 2013, 503, 397-401. [CrossRef]

6. Geoghegan, J.A.; Irvine, A.D.; Foster, T.J. Staphylococcus aureus and Atopic Dermatitis: A Complex and Evolving Relationship. Trends Microbiol. 2018, 26, 484-497. [CrossRef]

7. Nakatsuji, T.; Chen, T.H.; Narala, S.; Chun, K.A.; Two, A.M.; Yun, T.; Shafiq, F.; Kotol, P.F.; Bouslimani, A.; Melnik, A.V.; et al. Antimicrobials from human skin commensal bacteria protect against Staphylococcus aureus and are deficient in atopic dermatitis. Sci. Transl. Med. 2017, 9, eaah4680. [CrossRef]

8. Jang, I.-T.; Yang, M.; Jo, E.-K.; Kim, H.-J.; Park, J.-K. The Effects of Staphylococci on the Degranulation of Human Mast Cell-1. J. Bacteriol. Virol. 2017, 47, 132. [CrossRef]

9. Iwamoto, K.; Moriwaki, M.; Miyake, R.; Hide, M. Staphylococcus aureus in atopic dermatitis: Strain-specific cell wall proteins and skin immunity. Allergol. Int. 2019, 68, 309-315. [CrossRef]

10. Williams, M.R.; Gallo, R.L. The Role of the Skin Microbiome in Atopic Dermatitis. Curr. Allergy Asthma Rep. 2015, 15, 65. [CrossRef] 
11. Hepburn, L.; Hijnen, D.; Sellman, B.; Mustelin, T.; Sleeman, M.; May, R.; Strickland, I. The complex biology and contribution of Staphylococcus aureus in atopic dermatitis, current and future therapies. Br. J. Dermatol. 2017, 177, 63-71. [CrossRef]

12. Zipperer, A.; Konnerth, M.C.; Laux, C.; Berscheid, A.; Janek, D.; Weidenmaier, C.; Burian, M.; Schilling, N.A.; Slavetinsky, C.; Marschal, M.; et al. Human commensals producing a novel antibiotic impair pathogen colonization. Nature 2016, 535, 511-516. [CrossRef] [PubMed]

13. Williams, M.R.; Gallo, R.L. Evidence that Human Skin Microbiome Dysbiosis Promotes Atopic Dermatitis. J. Investig. Dermatol. 2017, 137, 2460-2461. [CrossRef]

14. Christensen, G.J.M.; Scholz, C.F.P.; Enghild, J.J.; Rohde, H.; Kilian, M.; Thürmer, A.; Brzuszkiewicz, E.; Lomholt, H.B.; Brüggemann, H. Antagonism between Staphylococcus epidermidis and Propionibacterium acnes and its genomic basis. BMC Genom. 2016, 17, 152. [CrossRef]

15. Otto, M. Staphylococcus epidermidis: a major player in bacterial sepsis? Futur. Microbiol. 2017, 12, 1031-1033. [CrossRef]

16. Siljamäki, P.; Varmanen, P.; Kankainen, M.; Sukura, A.K.K.; Savijoki, K.; Nyman, T.A. Comparative Exoprotein Profiling of DifferentStaphylococcus epidermidisStrains Reveals Potential Link between Nonclassical Protein Export and Virulence. J. Proteome Res. 2014, 13, 3249-3261. [CrossRef]

17. Götz, F.; Perconti, S.; Popella, P.; Werner, R.; Schlag, M. Epidermin and gallidermin: Staphylococcal lantibiotics. Int. J. Med Microbiol. 2014, 304, 63-71. [CrossRef]

18. Bjerre, R.; Bandier, J.; Skov, L.; Engstrand, L.; Johansen, J. The role of the skin microbiome in atopic dermatitis: A systematic review. Br. J. Dermatol. 2017, 177, 1272-1278. [CrossRef]

19. Lee, D.C.; Kananurak, A.; Tran, M.T.; Connolly, P.A.; Polage, C.R.; Iwase, T.; Bevins, C.L.; Underwood, M.A. Bacterial Colonization of the Hospitalized Newborn: Competition Between Staphylococcus aureus and Staphylococcus epidermidis. Pediatr. Infect. Dis. J. 2019, 38, 682-686. [CrossRef]

20. Lambers, H.; Piessens, S.; Bloem, A.; Pronk, H.; Finkel, P. Natural skin surface pH is on average below 5, which is beneficial for its resident flora. Int. J. Cosmet. Sci. 2006, 28, 359-370. [CrossRef]

21. Sandiford, S.; Upton, M. Identification, characterization, and recombinant expression of epidermicin NI01, a novel unmodified bacteriocin produced by Staphylococcus epidermidis that displays potent activity against Staphylococci. Antimicrob Agents Ch. 2012, 56, 1539-1547. [CrossRef]

22. Byrd, A.L.; Belkaid, Y.; Segre, J.A. The human skin microbiome. Nat. Rev. Genet. 2018, 16, 143-155. [CrossRef]

23. Cogen, A.L.; Yamasaki, K.; Sanchez, K.M.; Dorschner, R.A.; Lai, Y.; MacLeod, D.T.; Torpey, J.W.; Otto, M.; Nizet, V.; Kim, J.E.; et al. Selective antimicrobial action is provided by phenol-soluble modulins derived from Staphylococcus epidermidis, a normal resident of the skin. J. Investig. Dermatol. 2010, 130, $192-200$. [CrossRef] [PubMed]

24. Claudel, J.-P.; Auffret, N.; Leccia, M.-T.; Poli, F.; Corvec, S.; Dréno, B. Staphylococcus epidermidis: A Potential New Player in the Physiopathology of Acne? Dermatology 2019, 235, 287-294. [CrossRef] [PubMed]

25. Iwase, T.; Uehara, Y.; Shinji, H.; Tajima, A.; Seo, H.; Takada, K.; Agata, T.; Mizunoe, Y. Staphylococcus epidermidis Esp inhibits Staphylococcus aureus biofilm formation and nasal colonization. NPG 2010, 465, 346-349. [CrossRef] [PubMed]

26. Bürgers, R.; Morsczeck, C.; Felthaus, O.; Gosau, M.; Beck, H.; Reichert, T.E. Induced surface proteins of Staphylococcus [corrected] epidermidis adhering to titanium implant substrata. Clin. Oral Investig. 2018, 22, 2663-2668. [CrossRef] [PubMed]

27. Alreshidi, M.M.; Dunstan, R.H.; Gottfries, J.; Macdonald, M.M.; Crompton, M.J.; Ang, C.-S.; Williamson, N.A.; Roberts, T.K. Changes in the Cytoplasmic Composition of Amino Acids and Proteins Observed in Staphylococcus aureus during Growth under Variable Growth Conditions Representative of the Human Wound Site. PLOS ONE 2016, 11, 7. [CrossRef] [PubMed]

28. Mekonnen, S.A.; Medina, L.M.P.; Glasner, C.; Tsompanidou, E.; De Jong, A.; Grasso, S.; Schaffer, M.; Mäder, U.; Larsen, A.R.; Gumpert, H.; et al. Signatures of cytoplasmic proteins in the exoproteome distinguish community- and hospital-associated methicillin-resistantStaphylococcus aureusUSA300 lineages. Virulence 2017, 8, 891-907. [CrossRef]

29. García-Pérez, A.N.; De Jong, A.; Junker, S.; Becher, D.; Chlebowicz, M.A.; Duipmans, J.C.; Jonkman, M.F.; Van Dijl, J.M. From the wound to the bench: exoproteome interplay between wound-colonizing Staphylococcus aureus strains and co-existing bacteria. Virulence 2018, 9, 363-378. [CrossRef] 
30. Solis, N.; Cain, J.A.; Cordwell, S.J. Comparative analysis of Staphylococcus epidermidis strains utilizing quantitative and cell surface shaving proteomics. J. Proteom. 2016, 130, 190-199. [CrossRef]

31. García-Gómez, E.; Miranda-Ozuna, J.F.T.; Díaz-Cedillo, F.; Vázquez-Sánchez, E.A.; Rodríguez-Martínez, S.; Jan-Roblero, J.; Cancino-Diaz, M.E.; Cancino-Diaz, J.C. Staphylococcus epidermidis lipoteichoic acid: exocellular release and ltaS gene expression in clinical and commensal isolates. J. Med Microbiol. 2017, 66, 864-873. [CrossRef] [PubMed]

32. Pidutti, P.; Federici, F.; Brandi, J.; Manna, L.; Rizzi, E.; Marini, U.; Cecconi, D. Purification and characterization of ribosomal proteins L27 and L30 having antimicrobial activity produced by theLactobacillus salivariusSGL 03. J. Appl. Microbiol. 2018, 124, 398-407. [CrossRef] [PubMed]

(C) 2020 by the authors. Licensee MDPI, Basel, Switzerland. This article is an open access article distributed under the terms and conditions of the Creative Commons Attribution (CC BY) license (http://creativecommons.org/licenses/by/4.0/). 